\title{
Association between untreated dental caries and household food insecurity in schoolchildren
}

\author{
Associação entre cárie dentária não tratada \\ e insegurança alimentar em escolares
}

\author{
Gabriela Cristina Santin ${ }^{1}$ \\ Tatiana Pegoretti Pintarelli ${ }^{1}$ \\ Fabian Calixto Fraiz ${ }^{1}$ \\ Ana Cristina Borges de Oliveira ${ }^{2}$ \\ Saul Martins Paiva ${ }^{3}$ \\ Fernanda Morais Ferreira ${ }^{1}$
}

${ }^{1}$ Departamento de

Estomatologia, Universidade

Federal do Paraná. Av.

Lothário Meissner 632,

Jardim Botânico. 80210-

170 Curitiba PR Brazil.

gab_santin@hotmail.com

${ }^{2}$ Departamento de

Odontologia Preventiva e

Social, Universidade Federal

de Minas Gerais (UFMG).

Belo Horizonte MG Brasil.

${ }^{3}$ Departamento de

Odontopediatria e

Ortodontia, UFMG. Belo

Horizonte MG Brasil.
Abstract The aim of the present study was to assess the association between untreated dental caries (UDC) and household food insecurity (HFI) among schoolchildren in different income strata. A population-based study was carried out with a sample of 584 12-y-old schoolchildren. Oral examinations were performed and HFI was determined using a validated scale. Other independent variables were analyzed for being of interest to the stratification of the results (per capita household income) or for acting as potential confounding variables. The prevalence of UDC and HFI was $45 \%$ and $39 \%$, respectively. The multivariate models demonstrated that the UDC was significantly more prevalent among children in food-insecure households with per capita income of up to US\$ 70.71 than among those in the same income stratum that were free of HFI $[P R=1.52$ $(95 \% C I=1.01-2.29)]$. HFI was associated with a greater frequency of UDC among low-income schoolchildren, but had no significant impact on this variable among children from other income strata. Thus, ensuring access to quality food may be a good strategy for minimizing inequities in oral health and reducing dental caries experience among schoolchildren from low-income families. Key words Food insecurity, Dental caries, Child, Income
Resumo O objetivo deste estudo foi avaliar a associação entre cárie dentária não tratada (CDNT) e insegurança alimentar (IA) em escolares de diferentes estratos de renda. Foi realizado um estudo de base populacional com uma amostra de 584 escolares de 12 anos de idade. Exames clinicos bucais foram realizados e IA foi determinada por meio de uma escala validada. Outras variáveis foram analisadas por serem de interesse para a estratificação dos resultados (renda domiciliar per capita) ou como variáveis de confusão. A prevalência de CDNT e IA foi de 45\% e 39\%, respectivamente. Os modelos multivariados demonstraram que a CDNT foi significativamente mais prevalente entre as crianças com IA alimentar e renda per capita de até US\$ 70,71 do que entre aqueles no mesmo estrato de renda que estavam livres de IA $[R P=1,52($ IC 95\% = 1,01 -2,29)]. A IA foi associada com uma maior frequência de CDNT em escolares de baixa renda, porém não teve impacto significativo sobre esta variável entre crianças de diferentes estratos de renda. Diante disso, garantir o acesso a uma alimentação de qualidade pode representar uma boa estratégia para minimizar as iniquidades em saúde bucal e reduzir a experiência de cárie dentária em escolares de baixa renda. Palavras-chave Segurança alimentar e nutricional, Cárie dentária, Criança, Renda 


\section{Introduction}

Despite social advances over time, hunger and malnutrition remain important problems for humanity. Although access to adequate food is stipulated in the Universal Declaration of $\mathrm{Hu}-$ man Rights ${ }^{1}$, approximately one billion people throughout the world are malnourished ${ }^{2}$. In Brazil, 16 million people live below the poverty line and are unable to meet their basic food needs ${ }^{3}$.

Food insecurity (FI) is a concept that encompasses from concerns and anguish of individuals regarding the uncertainty of regularly obtaining food until the experience of hunger due to not eating for an entire day. Reducing dietary variety and the amount of food constitute strategies that are often employed to cope with this situation, which lead to an evident loss in nutritive quality $y^{4,5}$.

Despite their important association, poverty and FI do not comprise the same concept. Insufficient income hinders access to basic needs, such as food, clothing, housing, education and health care. However, an individual may be poor without being affected by hunger when his/her poverty is expressed by basic needs other than food $^{6}$. There are also situations in which access to food does not depend upon income. Children may receive meals offered in the school setting ${ }^{7}$, families may produce food crops for subsistence (family farming $)^{8}$ or receive foods from systemic donations. Moreover, families with an income above the poverty level may exhibit signs of FI due to other needs and priorities that compete with food needs?.

Individuals with FI generally have a diet that is rich in carbohydrates and fat ${ }^{10}$. The literature indicates that adults in this situation are more vulnerable to heart disease, diabetes, high blood pressure $^{11}$, obesity ${ }^{11-13}$ and stress ${ }^{12}$. FI appears to have adverse effects on the health of children and adolescents as well, with an increase in the rates of iron ${ }^{14}$ and zinc ${ }^{15}$ deficiency, acute infection, chronic diseases ${ }^{16}$, delayed cognitive development $^{17}$ and anxiety ${ }^{18}$. Divergent results are reported regarding the association between FI and overweight in children ${ }^{19-21}$. Further studies on this issue are needed.

Diet is also a determinant factor in the etiology of dental caries. Foods with high carbohydrate content, especially sucrose, are considered the most cariogenic. Bacteria found in dental biofilm (plaque) use sucrose in the glycolytic pathway and generate acids that can lead to the demineralization of teeth. Some bacteria use su- crose as a substrate for the production of intracellular and extracellular polysaccharides, which are important factors in the genesis of caries $^{22}$. Frequent sugar intake leads to the selection of acidogenic and acid uric bacteria in the biofilm capable of promoting the de-mineralization of the dental ename ${ }^{23}$. Thus, the high carbohydrate intake characteristic of individuals in a state of FI can alter the microbiological and biochemical composition of dental biofilm, making it more cariogenic.

Some studies have evaluated FI and oral health, identifying possible associations between these variables. A significant association was found among FI, the seeking of dental services and the type of treatment performed on children aged five to 14 years in New Zealand ${ }^{24-26}$. Another study involving individuals between 18 and 64 years of age in Canada found that low-income laborers in a situation of FI exhibited a greater frequency of denture use and toothache, with consequent chewing and working difficulties, in comparison to low-income laborers without $\mathrm{FI}^{27}$. However, the studies cited assessed oral health through self-reports of the interviewees, with no clinical examination performed and no dietary profile evaluated. Moreover, the samples comprised a wide age. FI was assessed using a small number of items that are insufficient for understanding all the dimensions of this condition, which ranges from a reduction in the amount of healthy foods to the replacement of foods and even complete restriction. Only one study was found having used a validated questionnaire to measure FI and clinical examination to assess dental caries, which found a highly association between these variables in 7- to 9-year-old Brazilian children from a town with a low Human Development Index score ${ }^{28}$.

Thus, the aim of the present study was to analyze the association between clinically diagnosed untreated dental caries (UDC) and household food insecurity (HFI) in different income strata of a representative sample of 12 -year-old schoolchildren, considering other risk variables for dental caries.

\section{Methods}

\section{Study design and sample}

A cross-sectional study was carried out with a multistage randomized sample representative of 12-year-old schoolchildren in a medium-sized 
southern city in Brazil (Araucária - Paraná), which has the second highest gross domestic product in its state and a human development index of 0.80 . The population in 2010 was estimated at 109,943 inhabitants, with 101,796 residing in urban areas ${ }^{29}$. Fluoridation of the public drinking water has occurred in the city since the early 1980s and the mean fluoride concentration in urban areas is $0.7 \mathrm{mg} / \mathrm{L}^{29}$. Data from the $\mathrm{Mu}$ nicipal Secretary of Education reveal that the city had 33 schools in urban areas in 2010, with a total of 2072 students aged 12 years $^{30}$. The decision to study a sample of 12-year-old schoolchildren was based on fact that the World Health Organization (WHO) considers this to be the index age for the assessment of caries in the permanent dentition of children ${ }^{31}$.

The calculation of the sample size was determined using the proportion estimate formula based on a prevalence value of $63.3 \%$ for dental caries among 12-year-olds ${ }^{32}$, a 95\% confidence level and maximal acceptable error of 5\%, considering a total population of 2072 schoolchildren. The minimal sample was determined to be 304 individuals, to which $60 \%$ as added to compensate for the cluster effect $(n=487)$ and a further $20 \%$ was added to compensate for possible losses, resulting in a total of 584 12-year-olds.

Two-stage (schools and children) randomized cluster sampling was employed. The sample was also stratified by regional administration districts ( 8 districts) and type of school (public and private). In the first stage, public and private schools were randomly selected by lots in each administration district for the acquisition of the determined number of students. In the second stage, 12-year-olds were randomly selected by lots from the selected schools aiming to maintaining the proportion of 12-year-old students enrolled at each district and each type of school using data from the sample size calculation. Data collection was carried out between March and September 2010.

The inclusion criteria were 12 years of age, enrollment in public or private schools in Araucaria city and absence of systemic disease (based on information provided by parents/guardians).

\section{Pilot Study}

A pilot study was carried out involving a convenience sample of 61 schoolchildren and their respective parents/guardians to test the methods and understanding of the data collection questionnaires and to draft a specific Food Frequency
Questionnaire (for counting the number of sugary foods consumed daily). The results revealed no need to change the initially proposed methods. The children enrolled in the pilot study were not included in the main sample.

\section{Data collection}

For the assessment of dental caries experience, the participants were submitted to a clinical examination at school using the decayed, missing and filled teeth (DMFT) index ${ }^{32}$. The clinical exam was performed by a single, previously calibrated examiner (TPP). The calibration process involved two steps. Theoretic activities involved a discussion on the diagnosis of different stages of caries using projected photographic images. In the practical step, 10 children were examined by the same examiner on two occasions, with a 15day interval between examinations. The dental professional who conducted the training of the examiner was considered the gold standard for the determination of inter-examiner agreement. The exams were carried out at the respective schools under natural light with the participants in the sitting position using a sterilized WHO ball point probe (Trinity ${ }^{\text {тм }}$, São Paulo, SP, Brazil), sterilized flat mouth mirror (Golgran ${ }^{\mathrm{T}}$, São Paulo, SP, Brazil) and individual protection equipment for the control of cross-infection. Sterilized gauze was used to clean and dry the dental surfaces.

HFI was assessed using the Brazilian Food Insecurity Scale (FIS-B), which is a version validated for Brazilian Portuguese ${ }^{33}$ of a measure developed in the United States of America for the assessment of $\mathrm{HFI}^{34}$. This assessment tool has a specific version for households with children and/or adolescents, which was filled out by the parents/guardians. The FIS-B for families is composed of 15 items with response options of 'yes (scored as 1)', 'no' (scored as zero) and 'doesn't know/doesn't want to answer' (not counted in the score calculation). The items address the family's experience with the insufficient food intake in the previous three months, including concerns with a possible lack of food and the possibility of going an entire day without food. Affirmative responses (yes $=1$ ) are summed (score range from 0 to 15 ), allowing the classification of the families into the following categories: food security (score: 0 ), mild FI (score: 1 to 5), moderate FI (score: 6 to 10 ) and severe FI (score: 11 to 15$)^{33}$.

Socioeconomic and demographic data were collected using a questionnaire filled out by the parents/guardians on the gender of the child, 
mother's schooling (nine categories ranging from 'did not study' to 'complete university education'), mother's marital status ('married/ stable union', 'single, 'widowed' and 'separated/ divorced'), number of children, number of residents in home and monthly household income. Income was analyzed based on the Brazilian minimum wage (BMW, equal to US\$284.00 at the time of the study conduction) divided by the number of residents in the home for the calculation of per capita household income. The questionnaire also contained a question on access to dental care 'Did your child ever need dental treatment and not received it because of your impossibility of affording it or getting an appointment for he/she at a public dental service?' ('yes', 'no') and a question on the time elapsed since the child's last dental visit ('less than 1 year,' ' 1 to 3 years ago,' ' 3 to 5 years ago', 'over 5 years ago', 'never').

The Food Frequency Questionnaire was used for the determination of sugar intake. This questionnaire was made up with the 20 foods (solids and liquids) which contained sugar in its composition most often reported to be consumed in the 24-hour logs by the participants in the pilot study $(n=61)^{35}$. The participants in the main study were instructed to choose an option ('never, 'less than once a month', ' 1 to 3 times a month', 'once a week', '2 to 4 times a week', 'once a day' and ' 2 or more times a day') that came closest to their consumption of each of the foods listed on the questionnaire. Every different food, solid or liquid, that was answered to be consumed at least once a day was computed and added to assess the total number of sugary foods consumed daily by each child.

The sweet taste preference was assessed using a modified version of the Sweet Preference Inventory $^{36}$, having the tea (Mate Leão ${ }^{\text {max }}$, Curitiba, PR, Brazil) as the vehicle, with the following concentrations of sucrose: $0.075 \mathrm{~mol} / \mathrm{L}, 0.15 \mathrm{~mol} / \mathrm{L}, 0.3$ $\mathrm{mol} / \mathrm{L}, 0.6 \mathrm{~mol} / \mathrm{L}$ and $0.9 \mathrm{~mol} / \mathrm{L}$. It was also added one sugar free option $(0.0 \mathrm{~mol} / \mathrm{L})$. The participants tasted one solution $(30 \mathrm{~mL})$ at a time in an increasing order of sugar concentration, alternating the ingestion of the solution with saltine crackers to desensitize the taste buds. At the end of the test, the participant chose the solution that most pleased him/her.

Samples of stimulated saliva were collected for the assessment of lactobacilli (LB) and mutans streptococci (MS) using the Dentalcult I and Dentalcult II laboratory kits (Laborclin ${ }^{\mathrm{nt}}$, Pinhais, PR, Brazil), respectively. In the school setting, the children were instructed to chew $2 \mathrm{~cm}^{2}$ of paraffin (Parafilm $\mathrm{M}^{\mathrm{Tw}}$, Laboratory Film, Chicago, USA), swallowing the saliva produced in the first minute and expectorating the saliva produced in the second and third minutes into a disposable plastic recipient. One aliquot of saliva was immediately used for inoculation of culture media on the surfaces of the slides of the Dentalcult I and II kits. A disk of bacitracin was then deposited on the surface of the culture medium of the Dentalcult II kit and a $\mathrm{CO}_{2}$ pellet was placed at the bottom of the flask. The flasks were incubated in a microbiological culture incubator at $37^{\circ} \mathrm{C}$ for 48 hours (Dentalcult II) or 72 hours (Dentalcult I). The number of colony-forming units (CFU) of MS and LB per $\mathrm{mL}$ of saliva in each sample was determined by similarities with the bacterial levels illustrated in the manufacturer's manual.

The children also answered a question on the frequency with which they brushed their teeth ('does not brush', 'once a day', 'twice a day', 'three or more times a day').

\section{Data analysis}

Data analysis involved the description of the absolute and relative frequencies of the variables according to the response variable 'UDC', which was dichotomized as 'present' (D component of DMFT index $\geq 1$ ) or 'absent' (D component of DMFT index $=0$ ). Univariate Poisson regression analyses were performed to determine associations between the response variable and independent variables. 'Brushing frequency', 'salivary levels of MS and LB', 'marital status', 'mother's schooling' and 'time since last dental visit' were dichotomized based on theoretic references. 'Number of children' and 'number of residents in home' were dichotomized by the median value. Sugar intake was categorized as ' 0 to 3', ' 4 to 6 ' and ' $\geq 7$ ' sugary foods consumed daily and sweet preference was categorized as 'low', 'medium' and 'high' concentrations of sugar. Household income was categorized based on the Brazilian poverty line, which considers families below fourth BMW per capita as in extreme poverty ${ }^{37}$. Thus, it was divided into the following strata: 'per capita income $\leq 1 / 4 \mathrm{BMW},{ }^{\prime} 1 / 4 \mathrm{BMW}<$ per capita income $\leq 1 / 2$ BMW', ' $1 / 2$ BMW $<$ per capita income $\leq 1$ BMW', per capita income $>1$ BMW'. HFI (main explanatory variable) was dichotomized as 'present' (FIS-B score $\geq 1$ ) or 'absent' (FIS-B score = $0)$. Multivariate Poisson regression models with robust variance were constructed to investigate the association between UDC and HFI in each 
income stratum, which allowed estimating prevalence ratios (PR) of UDC and respective 95\% confidence intervals (CI) for the groups of children with and without HFI, adjusted by the other independent variables. Variables with a p-value $<$ 0.20 in the univariate analysis were incorporated into the models. Biological, behavioral and socioeconomic variables that remained significant $(\mathrm{p} \leq 0.05)$ after adjustments were maintained in the final models ${ }^{38}$. HFI was maintained in all models regardless of the $\mathrm{p}$-value. The data were analyzed using the Statistical Package for the Social Sciences (SPSS for Windows, version 15.0, SPSS $^{\mathrm{TM}}$ Inc, Chicago, IL, USA).

The study was approved by the Committee for Ethics in Human Research of Universidade Federal do Paraná (Brazil) and carried out according to the Declaration of Helsinki. Consent was obtained from the parents/guardians and agreement was obtained from the children individually prior to the data acquisition procedures.

\section{Results}

A total of 538 children (318 girls and 220 boys) participated in the present study, representing a response rate of $92 \%$. The main reasons for the losses were the non-return of the questionnaires and the absence of the child on the day of the exam. Intra-examiner and inter-examiner Kappa values on a tooth-by-tooth basis were greater than 0.81 .

The mean DMFT index was 2.4 (standard deviation - SD: 2.3 ; median: 2 ). The prevalence of UDC (D component of DMFT index) was $45 \%$ (95\% CI: $41-50$ ); 54\% of the children had filled teeth (F component of DMFT index) and 0.7\% of the children had tooth loss due to caries (M component of DMFT index).

The prevalence of HFI was 39\% (95\% CI: $35-44) ; 28 \%$ of the children were in situation of mild HFI, 6\% had moderate HFI and 5\% had severe HFI. Total FIS-B scores ranged from 0 to 15 (mean: 1.9; SD: 3.5; median: 0). The questions with the greatest frequency of affirmative responses from parents/guardians were 'Were you worried that the food at home would run out before you could afford to buy or received more?' (27.9\%), 'Did you run out of money for a healthy, varied diet?' (25.7\%), 'Did you have to get by with only a few foods because the money ran out?' (23.2\%), 'Were you unable to offer your children a healthy, varied meal because you had no money?' (21.9\%) (Table 1 ).
Sixteen percent of the children belonged to families with a per capita household income of up to $1 / 4 \mathrm{BMW} ; 31 \%$ belonged to families with a per capita household income above $1 / 4$ and less than $1 / 2$ BMW; $37 \%$ belonged to families with a per capita income above $1 / 2$ and less than 1 BMW and $16 \%$ belonged to families with a per capita income above 1 BMW.

The number of sugary foods consumed on a daily basis by the children ranged from 0 to 18 (mean: 6; SD: 4; median: 5).

The prevalence of untreated caries was greater among children who studied at public schools, those whose mothers had up to eight years of schooling, those in families with three or more children, those with five or more residents in the home, those with a per capita household income less than $1 / 2$ BMW and those in food-insecure households $(\mathrm{p}<0.05)$ (Table 2$)$.

The prevalence of UDC was greater among children with salivary levels of MS and LB $\geq 10^{5}$ CFUs/mL ( $p=0.004$ and 0.011 , respectively), those with a greater daily sugary foods intake $(\mathrm{p}<$ 0.05 ) and those who reported not brushing their teeth at least twice a day $(\mathrm{p}<0.001)$ (Table 3$)$.

Children in households with more severe situations of FI exhibited a greater daily consumption of sugary foods (Chi-square test for linear trend, $\mathrm{p}<0.001)$. A significant association was found between income and HFI, as a lower per capita household income denoted higher HFI prevalence and severity values (Chi-square test for linear trend, $\mathrm{p}<0.001)$.

The Poisson multivariate models stratified by income and adjusted for brushing frequency, salivary levels of MS and LB, number of sugary foods consumed daily and mother's schooling care demonstrated that HFI was associated with UDC only in the children with a per capita income $\leq 1 / 4$ BMW $(p=0.045)$ (Table 4$)$.

\section{Discussion}

In the present study, UDC was associated with HFI. Only one study that investigated the impact of FI on clinically evaluated dental caries experience was found in the literature, which was conducted with Brazilian Amazon children ${ }^{28}$. Regardless minor differences in the study population (age and socio-economic contexts), the survey in Amazon also observed an association between dental caries and HFI in children. Likewise, previous studies using self-reports of oral health have indicated this association, when car- 
Table 1. FIS-B responses of parent/guardian of 12-year-olds, according to the last three months. Araucária city, Brazil $(\mathrm{n}=538)$.

\begin{tabular}{|c|c|c|c|c|c|c|}
\hline \multirow{2}{*}{$\begin{array}{l}\text { Questions } \\
\text { e food ran out before the house could } \\
\text { ore? }\end{array}$} & \multicolumn{2}{|c|}{$\begin{array}{c}\text { Yes } \\
\text { n }(\%)\end{array}$} & \multicolumn{2}{|c|}{$\begin{array}{l}\text { No } \\
\text { n }(\%)\end{array}$} & \multicolumn{2}{|c|}{$\begin{array}{c}\text { Doesn't know/ } \\
\text { Doesn't want } \\
\text { to answer } \\
\text { n }(\%)\end{array}$} \\
\hline & 150 & $(27.9)$ & 327 & $(60.8)$ & 61 & $(11.3)$ \\
\hline Did the food run out before you had money to buy more? & 88 & $(16.4)$ & 386 & $(71.7)$ & 64 & $(11.9)$ \\
\hline Did you run out of money for a healthy, varied diet? & 138 & $(25.7)$ & 340 & $(63.2)$ & 60 & $(11.2)$ \\
\hline Did you to get by with only a few foods because the money ran out? & 125 & $(23.2)$ & 356 & $(66.2)$ & 57 & $(10.6)$ \\
\hline $\begin{array}{l}\text { Were you unable to offer your children a healthy, varied meal } \\
\text { because you had no money? }\end{array}$ & 118 & $(21.9)$ & 353 & $(65.6)$ & 67 & $(12.5)$ \\
\hline $\begin{array}{l}\text { Did the children not eat enough because there was no money to buy } \\
\text { more? }\end{array}$ & 54 & $(10.0)$ & 416 & $(77.3)$ & 68 & (12.6) \\
\hline $\begin{array}{l}\text { Did an adult at home any time decrease the amount of food or skip } \\
\text { meals because there was not enough money to buy more? }\end{array}$ & 58 & (10.8) & 414 & $(77.0)$ & 66 & $(12.3)$ \\
\hline $\begin{array}{l}\text { Did you ever eat less than felt you should because there was no } \\
\text { money to buy more? }\end{array}$ & 54 & $(10.0)$ & 403 & $(74.9)$ & 81 & $(15.1)$ \\
\hline $\begin{array}{l}\text { Have you ever felt hungry but did not eat because they could not } \\
\text { afford enough food? }\end{array}$ & 38 & $8 \quad(7.1)$ & 411 & (76.4) & 89 & (16.5) \\
\hline $\begin{array}{l}\text { Did any adult at home lose weight because they do not have enough } \\
\text { money to buy food? }\end{array}$ & 24 & $4 \quad(4.5)$ & 426 & $(79.2)$ & 88 & (16.4) \\
\hline $\begin{array}{l}\text { Did any adult ever spend a whole day without eating or just had a } \\
\text { meal because there was no money to buy more? }\end{array}$ & 31 & $1 \quad(5.8)$ & 419 & (77.9) & 88 & (16.4) \\
\hline $\begin{array}{l}\text { Have you ever reduced the amount of food children's meals because } \\
\text { there was no money to buy more? }\end{array}$ & 42 & $2 \quad(7.8)$ & 413 & $(76.8)$ & 83 & (15.4) \\
\hline $\begin{array}{l}\text { Have you ever had to skip a meal for children because there was no } \\
\text { money to buy food? }\end{array}$ & 36 & $6 \quad(6.7)$ & 415 & (77.1) & 87 & $(16.2)$ \\
\hline Were the children hungry, but you just could not afford more food? & 25 & $5(4.6)$ & 429 & $(79.7)$ & 84 & $(15.6)$ \\
\hline $\begin{array}{l}\text { Were the children without food for a whole day because there was } \\
\text { no money to buy more food? }\end{array}$ & 25 & $5(4.6)$ & 428 & $(79.6)$ & 85 & (15.8) \\
\hline
\end{tabular}

ies was represented by outcomes such as 'presence of toothache at night or in the previous month', 'denture use' and 'previous experience with restorations and extractions' in children between five and 14 years of age in New Zealand ${ }^{24-26}$ and low-income laborers between 18 and 64 years of age in Canada ${ }^{27}$.

In the present state of knowledge regarding the etiology of dental caries, it is unacceptable for studies addressing factors associated with this outcome to disregard its classic determinants, such as demographic, socioeconomic, behavior and biological factors. The present study corroborates associations reported in the literature between dental caries and the number of children ${ }^{39}$, income ${ }^{40-42}$, number of residents in home ${ }^{43}$, type of school ${ }^{43}$, mother's schooling ${ }^{41}$, sugar intake ${ }^{44}$, brushing frequency ${ }^{40,42,44}$ and salivary levels of MS and $\mathrm{LB}^{45}$. These findings strengthen the notion that dental caries constitute a multifactor condition and confer credibility to both the method employed and the results obtained regarding HFI.

The use of a multivariate model involving explicative variables on different levels for the evaluation of the association between HFI and dental caries is a strong point of the present study, allowing the avoidance of the interference of confounding variables regarding the effect found among the variables of interest and ensuring greater accuracy in the findings. Moreover, the inclusion of microbiological factors in this analysis fills a gap often found in field studies. Despite the recognized importance of biological factors in the causal network of caries, it is difficult to evaluate variables that require laboratory support when large samples are involved.

One hypothesis that may explain the association between UDC and HFI is that FI leads 
Table 2. Association between untreated dental caries and demographic / socioeconomic variables in 12-year-old schoolchildren. Araucária city, Brazil $(\mathrm{n}=538)$.

\begin{tabular}{|c|c|c|c|c|c|}
\hline \multirow[b]{2}{*}{ Variables } & \multicolumn{3}{|c|}{ Untreated dental caries } & \multicolumn{2}{|c|}{ Univariate analysis } \\
\hline & $\begin{array}{c}\text { No } \\
\text { n }(\%)\end{array}$ & $\begin{array}{c}\text { Yes } \\
\text { n (\%) }\end{array}$ & $\begin{array}{c}\text { Total } \\
\mathbf{n}^{*}(100 \%)\end{array}$ & $\mathbf{p}^{\dagger}$ & $\begin{array}{c}\text { PR } \\
(95 \% \mathrm{CI})\end{array}$ \\
\hline \multicolumn{6}{|l|}{ Household food insecurity } \\
\hline Absent & $191(58.6)$ & $135(41.4)$ & 326 & & 1 \\
\hline Present & $103(48.6)$ & $109(51.4)$ & 212 & 0.021 & $1.24(1.03-1.49)$ \\
\hline \multicolumn{6}{|l|}{ Gender of child } \\
\hline Female & $114(51.8)$ & $106(48.2)$ & 220 & & 1 \\
\hline Male & $180(56.6)$ & $138(43.4)$ & 318 & 0.27 & $1.11(0.92-1.34)$ \\
\hline \multicolumn{6}{|l|}{ Type of school of child } \\
\hline Private & $31(86.1)$ & $5(13.9)$ & 36 & & 1 \\
\hline Public & $263(52.4)$ & $239(47.6)$ & 502 & 0.003 & $3.42(1.51-7.75)$ \\
\hline \multicolumn{6}{|l|}{ Mother's schooling } \\
\hline More than 8 years of schooling & $163(60.4)$ & $107(39.6)$ & 270 & & 1 \\
\hline Until 8 years of schooling & $122(50.2)$ & $121(49.8)$ & 243 & 0.021 & $1.26(1.04-1.52)$ \\
\hline \multicolumn{6}{|l|}{ Marital status of mother } \\
\hline Married or in stable union & $223(56.7)$ & $170(43.3)$ & 393 & & 1 \\
\hline Single, widowed or separated/divorced & $63(51.6)$ & $59(48.4)$ & 122 & 0.31 & $1.12(0.90-1.39)$ \\
\hline \multicolumn{6}{|l|}{ Number of children } \\
\hline Until 3 children & $232(62.4)$ & $140(37.6)$ & 372 & & 1 \\
\hline 4 or more children & $54(38.8)$ & $85(61.2)$ & 139 & $<0.001$ & $1.63(1.35-1.96)$ \\
\hline \multicolumn{6}{|l|}{ Number of residents in home } \\
\hline Until 4 people & $163(61.0)$ & $104(39.0)$ & 267 & & 1 \\
\hline 5 or more people & $123(49.8)$ & $124(50.2)$ & 247 & 0.011 & $1.29(1.06-1.56)$ \\
\hline \multicolumn{6}{|l|}{ Per capita household income } \\
\hline Income $>1 \mathrm{BMW}$ & $50(67.6)$ & $24(32.4)$ & 74 & & 1 \\
\hline $1 / 2 \mathrm{BMW}<$ income $\leq 1 \mathrm{BMW}$ & $103(58.9)$ & $72(41.1)$ & 175 & 0.21 & $1.27(0.87-1.84)$ \\
\hline $1 / 4 \mathrm{BMW}<$ income $\leq 1 / 2 \mathrm{BMW}$ & $74(51.4)$ & $70(48.6)$ & 144 & 0.032 & $1.50(1.04-2.17)$ \\
\hline Income $\leq 1 / 4 \mathrm{BMW}$ & $33(45.2)$ & $40(54.8)$ & 73 & 0.008 & $1.69(1.35-1.96)$ \\
\hline \multicolumn{6}{|l|}{ Last visit of the children to the dentist } \\
\hline In the last year & $225(57.5)$ & $166(42.5)$ & 391 & & 1 \\
\hline Over a year ago & $58(49.2)$ & $60(50.8)$ & 118 & 0.09 & $1.20(0.97-1.48)$ \\
\hline \multicolumn{6}{|l|}{ Cost prohibiting access to dental care } \\
\hline No & $191(56.7)$ & $146(43.3)$ & 337 & & 1 \\
\hline Yes & $92(53.5)$ & $80(46.5)$ & 172 & 0.49 & $1.07(0.88-1.31)$ \\
\hline
\end{tabular}

PR, prevalence ratio; CI, confidence interval; BMW, Brazilian minimum wage (about US\$284.00 at the time of the study conduction). ${ }^{*}$ Frequencies lower than 538 are due to missing data. ${ }^{\dagger}$ Univariate Poisson regression analysis. Results significant at $5 \%$ level marked in bold.

to an increase in sugar intake. Households in a situation of FI are more likely to purchase foods with a high energy density that are poor in nutrients and contain refined carbohydrates, fats and added sugar ${ }^{46}$. The present study represents advancement in comparison to previous studies investigating the relationship between dental caries and $\mathrm{FI}^{24-28}$ by analyzing the dietary profile of the children and demonstrating that the consumption of sugary foods was greater among children in food-insecure households, especially in those with severe HFI.
This hypothesis is supported by the analysis of the responses to the items of the FIS-B. Three of the four questions with the highest rate of affirmative answers ('Did you run out of money for a healthy, varied diet?', 'Did you have to get by with only a few foods because the money ran out?' and 'Were you unable to offer your children a healthy, varied meal because you had no money?') regarded the qualitative rather than quantitative nature of food restrictions, resulting in an unhealthy eating pattern with the replacement of foods. However, when 'intakes of sugary food' 


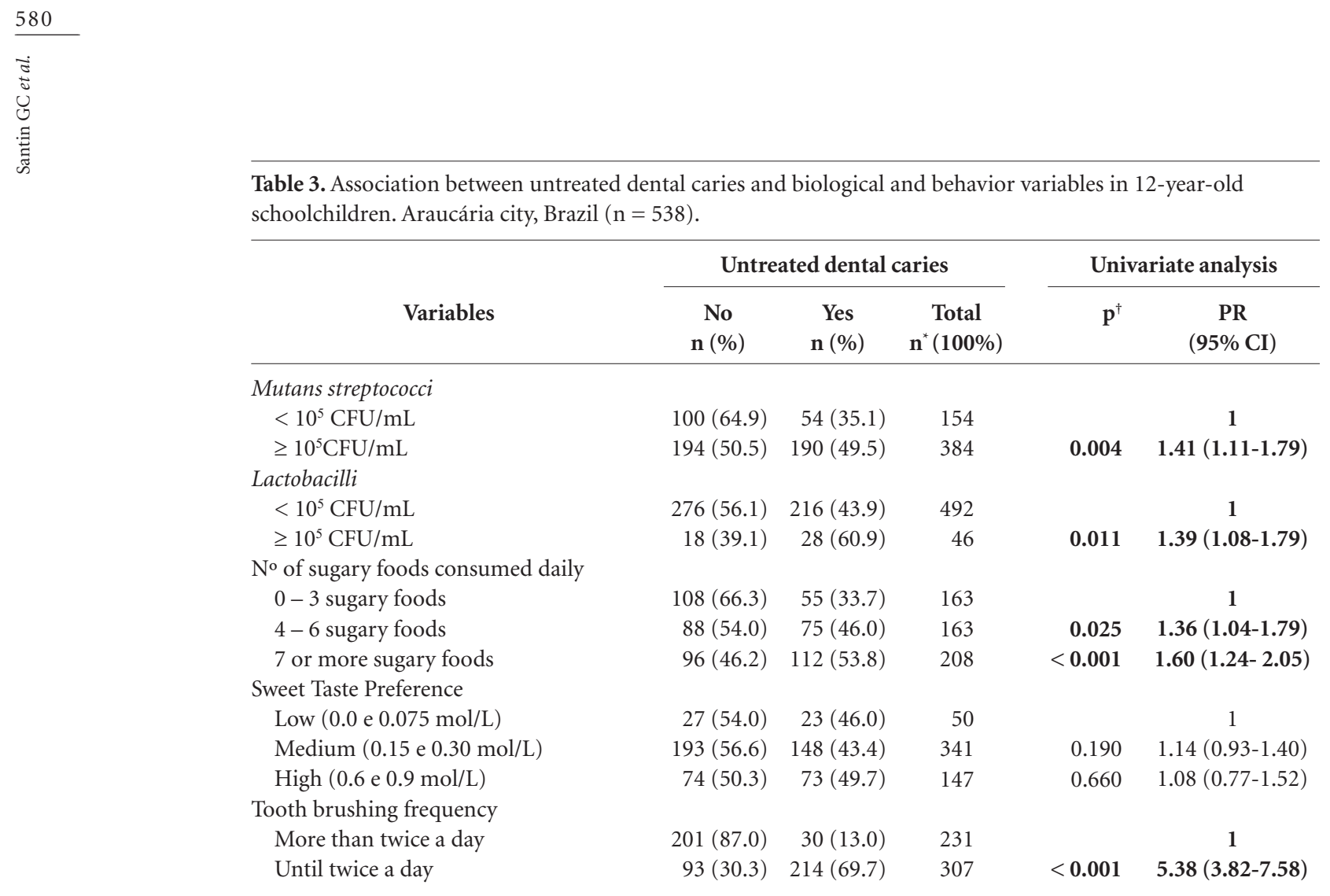

PR, prevalence ratio; $\mathrm{CI}$, confidence interval. * Frequencies lower than 538 are due to missing data.

${ }^{\dagger}$ Univariate Poisson regression analysis. Results significant at 5\% level marked in bold.

had been included in the multiple model, the statistical significance of HFI was maintained. So, there must be other aspects of FI beyond an increase in sugar intake influencing the dental caries experience.

Another strong point of the present study was the analysis of the association between dental caries and HFI for each income stratum. Income has been described as the most important variable in the determination of HFI in Brazil ${ }^{47}$. Households with a monthly income of less than two times the BMW have an approximately 13fold greater chance of being in a situation of moderate to severe FI and a 2.9-fold chance of being in a situation of mild $\mathrm{FI}^{48}$. As this finding was confirmed in the present study and, based on the belief that, regardless the collinearity of these variables, income and FI comprise distinct constructs, the decision was made to stratify the analyses by income.

The stratified analyses demonstrated that the association between dental caries and HFI does not occur in the same fashion in the different income strata. The finding that dental caries in schoolchildren was influenced by HFI only in the lowest income stratum may be explained by the greater severity of FI in this stratum. In a family, children are only affected by more severe degrees of FI, whereas adults are the ones affected and children are generally spared in situations of mild degrees of $\mathrm{FI}^{49}$. Moreover, HFI in higher income strata may represent unexpected economic changes in the family structure, with the emergence of factors that may temporarily compete with the food budget ${ }^{21}$ and incapability of managing their finances ${ }^{50}$.

In a case-control study comparing families with an income above the poverty line in situations of mild FI and those with food security, the authors found that $37.5 \%$ of the former reported the loss of a job, the gain of another household member or the loss of food assistance ${ }^{50}$. Thus, HFI that affects higher income strata tends to be of short duration, which may not be enough to have an impact on oral health, as tooth decay is a chronic condition that depends on the exposure time to risk factors.

The finding that the association between dental caries and HFI occurs in the lowest income stratum suggests the need for food banks and/or assistance programs that can meet the needs of these families or income transference programs, 
Table 4. Multivariate Poisson regression models: Association between untreated dental caries and household food insecurity among 12-year-old schoolchildren, according to income strata. Araucária city, Brazil.

\begin{tabular}{|c|c|c|c|c|c|}
\hline \multirow[b]{2}{*}{ Models } & \multicolumn{3}{|c|}{ Untreated dental caries } & \multicolumn{2}{|c|}{ Multiple analysis } \\
\hline & $\begin{array}{c}\text { No } \\
\text { n (\%) }\end{array}$ & $\begin{array}{c}\text { Yes } \\
\text { n (\%) }\end{array}$ & $\begin{array}{c}\text { Total } \\
\text { n(100\%) }\end{array}$ & $\begin{array}{c}\mathbf{p} \\
\text { value }\end{array}$ & $\begin{array}{c}\text { Adjusted PR } \\
\text { [CI 95\%] }\end{array}$ \\
\hline \multicolumn{6}{|c|}{ Household per capita income $\leq 1 / 4$ BMW } \\
\hline Food security & $13(54.2)$ & $11(45.8)$ & 24 & & 1 \\
\hline Insecurity & $20(40.8)$ & $29(59.2)$ & 49 & 0.045 & $1.51[1.01-2.29]$ \\
\hline \multicolumn{6}{|c|}{$1 / 4<$ per capita income $\leq 1 / 2 \mathrm{BMW}$} \\
\hline Food security & $35(53.0)$ & $31(47.0)$ & 66 & & 1 \\
\hline Food insecurity & $39(50.0)$ & $39(50.0)$ & 78 & 0.482 & $1.10[0.83-1.46]$ \\
\hline \multicolumn{6}{|c|}{$1 / 2<$ per capita income $\leq 1$ BMW } \\
\hline Food security & $76(62.3)$ & $46(37.7)$ & 122 & & 1 \\
\hline Food insecurity & $27(50.9)$ & $26(49.1)$ & 53 & 0.609 & $1.08[0.80-1.45]$ \\
\hline \multicolumn{6}{|l|}{ Per capita income $>1$ BMW } \\
\hline Food security & $39(65.0)$ & $21(35.0)$ & 60 & & 1 \\
\hline Food insecurity & $11(78.6)$ & $3(21.4)$ & 14 & 0.473 & $0.74[0.33-1.67]$ \\
\hline
\end{tabular}

Adjusted PR, prevalence ratio adjusted by varying levels of salivary mutans streptococci and lactobacilli, frequency of tooth brushing, frequency of consumption of sugary foods and mother's schooling. CI, confidence interval; BMW, Brazilian minimum wage (about US\$284.00 at the time of the study conduction). Results significant at the $5 \%$ level marked in bold. Frequencies lower than 538 are due to lack of data to one of the variables of the model.

which may assist in reducing the prevalence of dental caries. Every 10 Reais (Brazilian currency corresponding to US\$ 5.57) in increased income in Brazilian families stemming from social transference programs increases the odds of food security by $8 \%$, especially in low-income households (per capita income up to $1 / 4 \mathrm{BMW})^{49}$. In the USA, a study demonstrated that access to breakfast at schools reduces the risk of mild $\mathrm{HFI}^{7}$. Another study realized in the New Zealand observed that offering supermarket vouchers to family with food-insecurity resulted in an increase in overall expenditure on food ${ }^{51}$. Thus, there is a need for changes in public policies and health promotion actions. An approach directed solely at the disease factor and its prevention has proven ineffective at times and there is a need for interventions that can reduce health inequalities through changes in the determinants of health ${ }^{52}$.

As the FIS-B provides information on a recent period (previous three months), the decision was made to assess tooth decay based on the presence of UDC and not the DMFT index, which includes filled and missing teeth and therefore may reflect a situation prior to the HFI event. Since untreated caries is also a measure of access to dental care, it would be possible for the moderating effect of income on HFI to be partially explained by the fact that low-income families with FI cannot afford to pay for dental treatment due to competing financial demands. However, in the present study, $77 \%$ of the children reported having visited the dentist in the previous year and UDC was not related to difficulties in access to health services.

The present study has the limitations of all cross-sectional studies, especially the lack of temporality, which limits reliability in establishing the direction of the associations. The study design and the assessment tool used for quantifying HFI do not allow identifying how long the individuals surveyed have been in a situation of FI. HFI represents the conditions of household members as a group and not necessarily the condition of any particular member, especially a child. Such information would be useful to a better understanding of the role of FI as an episodic or cyclic condition in the development of dental caries. As tooth decay has a chronic, cumulative nature, the effects of FI on oral health are expected to be greater when the situation persists for a longer period of time. Thus, longitudinal studies using instruments that provide individually referenced food security information for children are needed to allow a better understanding of the association between dental caries and FI. 


\section{Conclusions}

Being in a food-insecure household was associated with a greater frequency of untreated dental caries among low-income schoolchildren, but had no significant impact on this variable among children from other income strata.

Socioeconomic inequities are recognized to exert an influence on the occurrence of dental caries. Although the ways by which social disadvantages affect this outcome are not fully understood, the present findings indicate that actions aimed at ensuring access to quality food may be a good strategy for minimizing inequities in oral health and reducing caries experience among schoolchildren from low-income families.

\section{Collaborations}

GC Santin and TP Pintarelli participated in the study design, data collection, analysis and interpretation the results and writing the article. FC Fraiz and FM Ferreira participated in the study design, analysis and interpretation of results, writing and critical review of the article. ACB Oliveira and SM Paiva participated in the analysis and interpretation the results and critical review of the article. All authors approved the final version of the manuscript. 


\section{References}

1. United Nations. Universal declaration of human rights. [cited 2014 Oct 1]. Available from:http://www.onu.org. br/a-onu-em-acao/a-onu-e-os-direitos-humanos/

2. Food and Agriculture Organization of the United Nations. 925 million people chronic hungry world. [cited 2014 Oct 1]. Available from: http://www.fao.org.br/ 925mchw.asp

3. Brazil. Ministry of Social Development. [Internet]. [cited 2014 Oct 1]. Available from: http://www.mds. gov.br/brasilsemmiseria

4. Bickel G, Nord M, Price C, Hamilton W, Cook J. Measuring food security in the United States. Guide to measuring household food security, revised 2000. Alexandria: Food and Nutrition Service, Office of Analysis, Nutrition, and Evaluation, U.S. Department of Agriculture; 2000.

5. Kepple AW, Segall-Correa AM. Conceituando e medindo segurança alimentar e nutricional. Cien Saude Colet 2011; 16(1):187-199.

6. Hoffmann R. Determinants of food insecurity in Brazil: Analysis of data from PNAD 2004. Segurança Alimentar e Nutricional 2008; 15:49-61.

7. Bartfeld JS, Ahn HM. The school breakfast program strengthens household food security among low-income households with elementary school children. $J$ Nutr 2011; 141(3):470-475.

8. Wolfe WS, Frongillo Junior EA. Building household food-security measurement tools from the ground up. Food Nutr Bull 2001; 22:5-12.

9. Rose D. Economic determinants and dietary consequences of food insecurity in the United States. J Nutr 1999; 129(Supl. 2):517S-520S.

10. Monteiro CA. The extent of poverty, hunger and malnutrition in Brazil. Estudos Avançados São Paulo. 1995; 9:195-207.

11. Vozoris NT, Tarasuk VS. Household food insufficiency is associated with poorer health. J Nutr 2003; 133(1):120-126

12. Stuff JE, Casey PH, Szeto KL, Gossett JM, Robbins JM, Simpson PM, Connell C, Bogle ML. Household food insecurity is associated with adult health status. J Nutr 2004; 134(9):2330-2335.

13. Tanumihardjo SA, Anderson C, Kaufer-Horwitz M, Bode L, Emenaker NJ, Haqq AM, Satia JA, Silver HJ, Stadler DD. Poverty, obesity, and malnutrition: An international perspective recognizing the paradox. J Am Diet Assoc 2007; 107(11):1966-1972.

14. Skalicky A, Meyers AF, Adams WG, Yang Z, Cook JT, Frank DA. Child food insecurity and iron deficiency anemia in low-income infants and toddlers in the United States. Matern Child Health J 2006; 10(2):177-185.

15. Pedraza DF, Queiroz D, Paiva AA, Cunha MAL, Lima ZN. Seguridad alimentaria, crecimiento y niveles de vitamina $A$, hemoglobina y zinc en niños pré-escolares del nordeste de Brasil. Cien Saude Colet 2014; 19(2):641-650.

16. Kursmark M, Weitzman M. Recent findings concerning childhood food insecurity. Curr Opin Clin Nutr Metab Care 2009; 12(3):310-316.
17. Rose-Jacobs R, Black MM, Casey PH, Cook JT, Cutts DB, Chilton M, Heeren T, Levenson SM, Meyers AF, Frank DA. Household food insecurity: associations with at risk infant and toddler development. Pediatrics 2008;121(1):65-72.

18. Whitaker RC, Phillips SM, Orzol SM. Food insecurity and the risks of depression and anxiety in mothers and behavior problems in their preschool-aged children. Pediatrics 2006; 118(3):e859-e868.

19. Matheson DM, Varady J, Varady A, Killen JD. Household food insecurity and nutritional status of Hispanic children in the fifth grade. Am J Clin Nutr 2002; 76(1):210-217.

20. Casey PH, Simpson PM, Gossett JM, Bogle ML, Champagne CM, Connell C, Harsha D, McCabe-Sellers B, Robbins JM, Stuff JE, Weber J. The association of child and household food insecurity with childhood overweight status. Pediatrics 2006; 118(5):e1406-e1413.

21. Rose D, Bodor JN. Household food insecurity and overweight status in young school children: results from the Early Childhood Longitudinal Study. Pediatrics 2006; 117(2):464-473.

22. Dibdin GH, Shellis RP. Physical and biochemical studies of Streptococcus mutans sediments suggest new factors linking the cariogenicity of plaque with its extracellular polysaccharide content. J Dent Res 1988; 67(6):890-895.

23. Nobre dos Santos M, Melo dos Santos L, Francisco SB, Cury JA. Relationship among dental plaque composition, daily sugar exposure and caries in the primary dentition. Caries Res 2002; 36(5):347-352.

24. Jamieson LM, Koopu PI. Predictor of dental pain and general anesthetic receipt for hospital dental procedures among New Zealand children. J Public Health Dent 2006; 66(3):192-198.

25. Jamieson LM, Koopu PI. Exploring factors that influence child use of dental services and toothbrushing in New Zealand. Community Dent Oral Epidemiol 2006; 34(6):410-418.

26. Jamieson LM, Koopu PI. Child use of dental services and receipt of dental care in New Zealand. J Paediat Child Health 2001; 43(11):732-739.

27. Muirhead V, Quiñonez C, Figueiredo R, Locker D. Oral health disparities and food insecurity in working poor Canadians. Community Dent Oral Epidemiol 2009; 37(4):294-304.

28. Frazão P, Benicio MHD, Narvai PC, Cardoso MA. Food insecurity and dental caries in schoolchildren: a cross-sectional survey in the western Brazilian Amazon. Eur J Oral Sci 2014; 122(3):210-215.

29. Paraná Institute of Economic and Social Development. Profile of the Municipality of Araucaria, 2006. [cited 2014 Oct 1]. Available from: http://www.ipardes. gov.br/perfil_municipal/MontaPerfil.php?Municipi$\mathrm{o}=83700 \& \mathrm{bt}$ 
30. Brazil. Ministry of Education. National Institute of Educational Studies. Preliminary Results of the 2008 School Census - Educacenso. [cited 2015 Dec 12]. Available from: http://www.inep.gov.br/basica/censo /Escolar/Matricula/censoescolar_2008.asp?metodo $=1 \&$ ano $=2008 \&$ UF $=$ PARAN $\%$ C $1 \&$ MUNICIPIO $=$ araucaria\&Submit $=$ Consulta

31. World Health Organization (WHO). Oral health surveys: basic methods. $4^{\text {th }}$ ed. Genebra: WHO; 1997.

32. Brazil. Ministry of Health. National Coordination of Oral Health. Project SB Brazil 2003: oral health status of the Brazilian population 2002-2003. Main results. [cited 2015 Dec 12]. Available from: http://bvsms. saude.gov.br/bvs/publicacoes/ projeto_sb2004.pdf

33. Pérez-Escamilla R, Segall-Corrêa AM, Maranha LK, Sampaio MFA, Marín-León L, Panigassi G. An adapted version of the U.S. Department of Agriculture Food Insecurity module is a valid tool for assessing household food insecurity in Campinas, Brazil. J Nutr 2004; 134(8):1923-1928.

34. United State Department of Agriculture. Household Food Security. [cited 2015 Dec 12]. Available from: http://www.ers.usda.gov/Publications/ERR49/ERR49b.pdf

35. Colucci ACA, Phillippi ST, Slater B. Steps for developing a food frequency questionnaire. Rev Bras Cienc Saude 2005; 3(6):7-12.

36. Jamel HA, Sheiham A, Cowell CR, Watt RG. Taste preference for sweetness in urban and rural populations in Iraq. J Dent Res 1996; 75(11):1879-1884.

37. Brazil. Decree nº. 7.492, Jun 2, 2011. Establishing the plan "Brazil without Poverty". Diário Oficial da União 2011; 3 Jun.

38. Hosmer DW, Lemeshow S. Applied logistic regression. $4^{\text {th }}$ ed. New York: Willey-Interscience Publication; 2000

39. Nicolau B, Marcenes W, Bartley M, Sheiham A. A life course approach to assessing causes of dental caries experience: the relationship between biological, behavioural, socio-economic and psychological conditions and caries in adolescents. Caries Res 2003; 37(5):319-326.

40. Mendes LGA, Biazevic MGH, Miguel-Crosato E, Mendes MOA. Dental caries and associated factors among Brazilian adolescents: a longitudinal study. Braz J Oral Sci 2008; 7(26):1614-1619.

41. Kim SW. Environmental, maternal, and child factors which contribute to early childhood caries: a unifying conceptual model. Int J Paediatr Dent 2012; 22(3):157168.

42. Brennan DS, Spencer AJ, Roberts-Thomson KF. Dental self-care and visiting behavior in relation to social inequality in caries experience. Community Dent Health 2011; 28(3):216-221.
43. Antunes JL, Frazão P, Narvai PC, Bispo CM, Pegoretti T. Spatial analysis to identify differentials in dental needs by area-based measures. Community Dent Oral Epidemiol 2002; 30(2):133-142.

44. Jürgensen N, Petersen PE. Oral health and the impact of socio-behavioral factors in a cross sectional survey of the 12-year old school children in Laos. BMC Oral Health 2009; 16(9):29.

45. Zukanović A, Muratbegović A, Kobašlija S, Marković N, Ganibegović M, BeŠlagić E. Relationships between socioeconomic backgrounds, caries associated microflora and caries experience in 12-year-olds in Bosnia and Herzegovina in 2004. Eur J Paediatric Dent 2008; 9(3):118-124.

46. Drewnowski A, Darmon N. Food choices and diets costs: an economic analysis. J Nutr 2005; 135(4):900904.

47. Reis M. Food insecurity and the relationship between household income and children's health and nutrition in Brazil. Health Econ 2012; 21(4):402-427.

48. Panigassi G, Segall-Corrêa AM, Marin-Leon L, Pérez -Escamilla R, Sampaio MFA, Maranha LK. Food insecurity as an indicator of inequity: analysis of a population survey. Cad Saude Publica 2008; 24(10):2376-2384.

49. Segall-Corrêa AM, Marin-Leon L, Helito H, Perez-Escamilla R, Santos LMP, Paes-Sousa R. Cash transference and food insecurity in Brazil: analysis of national data. Rev Nutr 2008; 21(Supl.):39S-51S.

50. Gundersen C, Kreider B. Bounding the effects of food insecurity on children's health outcomes. J Health Econ 2009; 28(5):971-983.

51. Smith C, Parnell WR, Brown RC, Gray AR. Providing additional money to food-insecure households and its effect on food expenditure: a randomized controlled trial. Public Health Nutr 2013; 16(8):1507-1515.

52. Watt RG. Emerging theories into the social determinants of health: implications for oral health promotion. Community Dent Oral Epidemiol 2002; 30(4):241-247.

Artigo apresentado em 11/10/2014

Aprovado em 16/06/2015

Versão final apresentada em 18/06/2015 